\title{
Evaluation of Stable Balance Capacity by Using Bosu Ball Surfaces on Different Pressure Levels
}

\author{
ADELA BADAU1', DANA BADAU2*, RAZVAN SANDU ENOIU³ \\ ${ }^{1}$ University of Medicine, Pharmacy, Sciences and Technology of Targu Mures, Department of Physical Education, $38 \mathrm{Gh}$. \\ Marinescu Str., 540139, Targu Mures, Romania \\ ${ }^{2}$ University of Medicine, Pharmacy, Sciences and Technology of Targu Mures, Department of Movement Sciences, 38 Gh. \\ Marinescu Str., 540139, Targu Mures, Romania \\ ${ }^{3}$ Transilvania University of Brasov, Department of Sport Performance, 1 Universitatii Str., 500068, Brasov, Romania
}

\begin{abstract}
The purpose of the study was to evaluate the way in which bimanual and unimanual balanced balance values depend on the technical characteristics of using both Bosu ball surfaces in relation to three pressure levels: $0.6 \mathrm{~atm} ., 0.4 \mathrm{~atm}$. and $0.2 \mathrm{~atm}$. The results have shown that steady manual balance is dependent on the characteristics of the equipment used. The lower the ball's pressure, the balancebalance becomes worse. Testing the stable hand-balance on the round-up has scored better than the round-side down of Bosu ball.
\end{abstract}

Keywords: static balance, pressure, Bosu Ball, facial plank, round side up, round side down

A technology trend aims to optimize the human motric potential by using modern equipment with a diverse, attractive design that is tailored to the particularities of the subjects and to the specific objectives of the motric activities. From the variety of equipment used in fitness and neuro-motric recovery programs, Bosu Ball due to the properties and technical characteristics of elasticity, aerodynamic shape, density, weight, wear resistance, high vibration damping capacity, etc. may have multifunctional use.

Plastic materials have a very varied applicability in motor and physiotherapeutic activities targeting both sports and recovery equipment, as well as monitoring equipment [14]. The term Bosu comes from Both Sides Up, the equipment being invented in 1999 by David Weck, having a hemisphere form, offering the possibility of using the two parts with a different degree of instability [5]. The Bosu ball is made of plastic, having in its composition industrial fibers with special, adherent, semi-elastic qualities, with high resistance to pressure [6]. Bosu Ball's specificity is represented by its two faces, totally different both in shape and in terms of technical characteristics, with a diameter of $65 \mathrm{~cm}$, a weight of $4.54 \mathrm{~kg}$ and a maximum weight of $120 \mathrm{~kg}$ [7-9].

The flat part is durable, plasticized, with round shape being predominantly used for posture correction, balance improvement, tonicity of the body muscles, involving a specific execution mode related to the position of the body. The hemispheric side, more unstable depending on the air pressure, offers more possibilities for practicing, as well as the possibility of developing reaction speed and motor control.

Studying literature, there is a multitude of studies performed on Bosu ball, in the lower limbs [10,11], for the development of the balance [1,12], for the development of the motor qualities and skills [13-15] and especially of the force and postural control [16-18].

The sense of balance is influenced by the quality of the central nervous system and the plasticity of the cerebral cortex. Thus, the cerebral cortex integrates the activity of the kinesthetic analyzers on the basis of which itelaborates the contraction impulses, related to the posture and the duration of its maintenance, in relation to the spatial and temporal characteristics.

Postural control and health-related balance have determinant roles in human motor capacity, targeting athletic performance and neuro-motor recovery and functional rehabilitation [19-25]. Specialists in the field of physical activities recommend the use of Bosu Ball in three types of specific training: cardio, human balance and postural control [26-27].

The specificity of using Bosu ball in our study is to maintain a certain stable position - the facial plank, for a long time, maintaining a correct posture and find a direct correlation with three aspects: part of the water that is supported, the air pressure in the ball and the number of limbs involved in maintaining the posture.

The particular physical effort made in maintaining the facial Plank is characterized by the involvement of large muscle groups, the maximum contraction being recorded in the muscle, humeral, abdominal, muscular, and lower limb muscles [28-31]. The plan position is characterized by isometric contraction under balance conditions, based on the absolute force of the individuals and on identifying the optimal weight center. The maintenance of the facial plank is based on the level of physical skills that requires a permanent neuro-muscular control achieved by adjusting the muscular tone according to the intensity of the muscle contraction [32]. The balance thus maintained is the result of two categories of stimuli, some being external (texture and adhesion of the supporting surface) and other internal (the degree of muscle contraction) [33,34].

The novelty of our study consists in using Bosu ball bloated on three different pressures and using it on both rounds up and round side down. The analysis of literature of the technical specifications of the manufacturers concludes that the use of Bosu ball at different pressures can cause different kinetic and effort demands, but we have not identified any technical specification or concrete study in this regard.

In this context, the purpose of the study was to evaluate how the steady-state balance and unimanual balance values are dependent on the technical characteristics of

\footnotetext{
*email; dana.badau@umfst.ro, danabadau.brasov@gmail.com; Phone: +40723198391
} 
the use of both Bosu ball surfaces relative to three pressure levels: $0.6 \mathrm{~atm} ., 0.4 \mathrm{~atm}$. and $0.2 \mathrm{~atm}$.

\section{Experimental part}

\section{Materials and methods}

The study was carried out between NovemberDecember 2018 on a sample of 45 volunteer students, 21 (46.6\%) students from the Physical and Sports Education Program at University of Medicine, Pharmacy, Stcience and Technology from Targu Mures and 24 (53.4\%) students from the Faculty of Physical Education and Sports Sports from Transilvania University in Brasov.

The sample included male students with the dominant right arm, average age $X \pm$ SD $21.55 \pm$.78 years; average height $X \pm S D 178.31 \pm 5.81 \mathrm{~cm}$; average weight $X \pm S D$ $74.75 \pm 8.48 \mathrm{~kg}$; straight leg length $X \pm$ SD $59.00 \pm 2.45$ $\mathrm{cm}$, left arm length $X \pm S D 59.22 \pm 2.44 \mathrm{~cm}$, right palm width $X \pm S D 9.05 \pm .66$, left palm width $X \pm$ SD $9.01 \pm$ .70 , right palm length $X \pm S D 18.71 \pm .86$, left palm length $\mathrm{X} \pm \mathrm{SD} 18.74 \pm .84$.

\section{Procedura}

Anthropometric parameters were measured by electronic weight (weight), tallometer (height) and ruler (palm and palm measurements). Testing the static manual balance was done evaluating the time to maintain the facial plank in three hypostases: on both arms, on the right arm, on the left arm. The timer is started when the subject is in the correct position and is stopped at unbalance as a result of the following situations: the hand moves or flexes, the body becomes unbalanced, the body does not maintain its linear position in the facial plank. Time has elapsed since the subjects have kept their balance until unbalanced.
The tests aimed at timing the manual balance on both Bosu ball surfaces on three levels of inflation pressure 0.2 atm.., $0.4 \mathrm{~atm} . ., 0.6 \mathrm{~atm}$.. Testing was conducted in different testing sessions. The first session included balancing testing on both arms on the elastic side on the three levels of pressure in the ball, with 30 min breaks between testing. The second session aimed to test the balance on both arms on the hard side, plain on three levels of pressure in the ball, with 30 min breaks between testing. The third and fourth session recorded testing the balance in the facial plank position with only the right arm on both sides of the Bosu ball, on the three levels of the pressure in the ball, with 30 min breaks between testing. In the fifth and sixth sessions we tested the balance in the facial plank with support on the left arm on both surfaces of the Bosu ball, on the three levels of pressure in the ball, with 30 min breaks between. Between the sessions there was a break of at least $4 \mathrm{~h}$.

\section{Statistical analysis}

The results of the research were processed in SPSS 21, calculating the statistical indicators: arithmetic average $(\mathrm{X})$, standard deviation (SD), t - Student test, Pearson correlation ( $r$ ), Kolmogorov-Smirnov test of normality (Z), the significance threshold chosen $p \leq .05$.

\section{Results and discussions}

Analyzing Pearson ( $r$ ) correlation index values revealed statistically insignificant results between anthropometric and motor parameters, reflecting the fact that the maintenance time in the stable Bosu ball balance is not influenced by the dimensions of the upper limb somatic parameters.

The results of the Studenttest show that the results were statistically significant, for $p \leq 0.05$, the best results for all

Table 1

STATISTICAL DESCRIPTION OF THE RESULTS OF THE MANUAL STATIC BALANCE EVALUATION ON THE TWO BOSS BALL SURFACES ACCORDING TO THE THREE LEVELS OF LEAVING SUSPENSION

\begin{tabular}{|c|c|c|c|c|c|c|c|c|}
\hline $\begin{array}{l}\text { Bosu Ball } \\
\text { surfaces }\end{array}$ & Tests & $\begin{array}{l}\text { Pressure } \\
\text { (atm..) }\end{array}$ & $\mathrm{X}$ & $\mathrm{SD}$ & $\mathrm{t}$ & $\mathrm{p}$ & Z & $\begin{array}{l}\text { Asymp. } \\
\text { Sig. }\end{array}$ \\
\hline \multirow{9}{*}{$\begin{array}{l}\text { Round side } \\
\text { up }\end{array}$} & \multirow{3}{*}{$\begin{array}{l}\text { Facial plank on } \\
\text { both arms }\end{array}$} & 0.6 & 218.488 & 71.302 & 20.556 & .000 & .920 & .366 \\
\hline & & 0.4 & 191.777 & 57.392 & 22.416 & .000 & 1.154 & .140 \\
\hline & & 0.2 & 162.488 & 52.951 & 20.585 & .000 & .981 & .291 \\
\hline & \multirow{3}{*}{$\begin{array}{l}\text { Facial plank on } \\
\text { right arm }\end{array}$} & 0.6 & 116.777 & 42.952 & 18.238 & .000 & .785 & .568 \\
\hline & & 0.4 & 103.888 & 38.944 & 17.895 & .000 & 1.064 & .208 \\
\hline & & 0.2 & 89.666 & 34.796 & 17.286 & .000 & .870 & .435 \\
\hline & \multirow{3}{*}{$\begin{array}{l}\text { Facial plank on left } \\
\text { arm }\end{array}$} & 0.6 & 104.111 & 40.377 & 17.297 & .000 & .776 & .583 \\
\hline & & 0.4 & 89.511 & 37.546 & 15.992 & .000 & .963 & .312 \\
\hline & & 0.2 & 77.488 & 33.320 & 15.600 & .000 & .881 & .419 \\
\hline \multirow{9}{*}{$\begin{array}{l}\text { Round side } \\
\text { down }\end{array}$} & \multirow{3}{*}{$\begin{array}{l}\text { Facial plank on } \\
\text { both arms }\end{array}$} & 0.6 & 121.066 & 46.597 & 17.429 & .000 & 1.340 & .055 \\
\hline & & 0.4 & 109.288 & 44.184 & 16.593 & .000 & 1.319 & .059 \\
\hline & & 0.2 & 102.400 & 45.317 & 15.158 & .000 & 1.297 & .069 \\
\hline & \multirow{3}{*}{$\begin{array}{l}\text { Facial plank on } \\
\text { right arm }\end{array}$} & 0.6 & 65.111 & 25.199 & 17.333 & .000 & .832 & .494 \\
\hline & & 0.4 & 54.022 & 20.759 & 17.456 & .000 & 1.406 & .231 \\
\hline & & 0.2 & 43.866 & 19.644 & 14.980 & .000 & 1.130 & .156 \\
\hline & \multirow{3}{*}{$\begin{array}{l}\text { Facial plank on left } \\
\text { arm }\end{array}$} & 0.6 & 66.044 & 36.247 & 14.073 & .000 & 1.120 & .163 \\
\hline & & 0.4 & 57.733 & 26.540 & 14.592 & .000 & .991 & .280 \\
\hline & & 0.2 & 45.644 & 20.604 & 14.860 & .000 & 1.072 & .201 \\
\hline
\end{tabular}

X - mean, SD - standard deviation, t - Student test, p - probability level, Z - Test Sample Kolmogorov-Smimov normality,

Asymp. Sig. - asymptotic significance levels. 


\begin{tabular}{|l|c|c|c|c|c|}
\hline Paired of Bosu ball surfaces & $\begin{array}{c}\text { Pressure } \\
\text { (atm..) }\end{array}$ & $\mathrm{X}(\mathrm{sec}$.) & $\mathrm{SD}$ & $\mathrm{t}$ & $\mathrm{p}$ \\
\hline \multirow{2}{*}{$\begin{array}{l}\text { Both arms: Round side up - } \\
\text { Round side down }\end{array}$} & 0.6 & 106.288 & 78.365 & 9.099 & .000 \\
\cline { 2 - 6 } & 0.4 & 76.911 & 77.241 & 6.680 & .000 \\
\cline { 2 - 6 } & 0.2 & 53.044 & 60.667 & 5.865 & .000 \\
\hline \multirow{2}{*}{$\begin{array}{l}\text { Right arm: Round side up - } \\
\text { Round side }\end{array}$} & 0.6 & 51.666 & 38.618 & 8.975 & .000 \\
\cline { 2 - 6 } & 0.4 & 49.866 & 35.747 & 9.358 & .000 \\
\cline { 2 - 6 } & 0.2 & 45.800 & 33.194 & 9.256 & .000 \\
\cline { 2 - 6 } Left arm: Round side up - & 0.6 & 38.066 & 47.880 & 3.932 & .000 \\
\cline { 2 - 6 } Round side & 0.4 & 31.777 & 42.714 & 4.991 & .000 \\
\cline { 2 - 6 } & 0.2 & 31.844 & 32.678 & 6.537 & .000 \\
\hline
\end{tabular}

Table 2

STATISTICAL DESCRIPTION OF PAIRED DIFFERENCES OF THE STATIC BALANCE EVALUATION RESULTS IN FACIAL PLANK POSITION BETWEEN THE BOSS BALL SURFACES

$\mathrm{X}$ - mean, SD - standard deviation, $\mathrm{t}$ - Student test, $\mathrm{p}$ - probability level, atm. - atmosphere

tests were recoraed on the bosu pall at the intiation pressure of $0.6 \mathrm{~atm} .$, for both surfaces, and the lowest performances for the pressure $0.2 \mathrm{~atm}$.. The results for Kolmogorov-Smirnov Z reveal a normal and statistically significant distribution of the study results in all tests.

The difference in the tests by comparative analysis of the results recorded on the two sides of the Bosu ball (Round side up versus Round side) for all tests was statistically significant for $p \leq 0.05$. The biggest differences were recorded between the tests on the two surfaces for the test on both arms of $106.288 \mathrm{~s}$ at the pressure of 0.6 atm., and the lowest ones at the testing on the left arm of only $31.777 \mathrm{~s}$ at a pressure of $0.4 \mathrm{~atm}$.. For all Bosu ball pressure analysis, the results highlight the fact that on the round-side side the results are higher than on the round side-down. The analysis of the results highlights the fact that the higher the hemispheric ball pressure is, the lowest the balance maintaining capacity is.

The recorded differences were statistically significant for $p \leq 0.05$, indicating that the executions performed on balls whose pressure drops by only $0.2 \mathrm{~atm}$. (between 0.6-
$0.4 \mathrm{~atm}$. and $0.4-0.2 \mathrm{~atm}$.) are higher than those on which the pressure decreases with $0.4 \mathrm{~atm}$. (between $0.6 \mathrm{~atm}$. and $0.4 \mathrm{~atm}$.). Comparative analysis of pressure levels reveals that the biggest difference is between $0.6 \mathrm{~atm}$. and $0.2 \mathrm{~atm}$. for all tests.

The results highlight the biggest difference between tests on Bosu ball between 0.6-0.4 atm. levels of inflation pressure. It was registered within test on both arms for round side up; the smallest difference was recorded for the facial plank on the left-hand for the round side down. The biggest and most significant difference between the Bosu ball tests between the $0.4-0.2 \mathrm{~atm}$. pressure levels is recorded on the test on both arms for round side up; the smallest difference for both arms for round side down.

Comparison of results between Bosu ball pressure levels of $0.6 \mathrm{~atm}$.. and $0.2 \mathrm{~atm}$. reveals that all differences are statistically significant for $p \leq 0.05$. The biggest difference was registred on testing both arms for round side up, and the smallest difference for round side down for facial plank on both arms.

\begin{tabular}{|c|c|c|c|c|c|c|}
\hline Surfaces of Bosu ball & Arms & $\begin{array}{l}\text { Paired of ball } \\
\text { pressure }\end{array}$ & $\mathrm{X}$ & $\mathrm{SD}$ & $\mathrm{t}$ & $\mathrm{p}$ \\
\hline \multirow[t]{9}{*}{ Round side up } & \multirow[t]{3}{*}{ Both arms } & $0.6-0.4$ & 26.711 & 72.696 & 2.465 & .000 \\
\hline & & $0.4-0.2$ & 29.288 & 52.015 & 3.777 & .000 \\
\hline & & $0.6-0.2$ & 56.000 & 51.040 & 7.360 & .000 \\
\hline & \multirow[t]{3}{*}{ Right arm } & $0.6-0.4$ & 12.888 & 7.007 & 12.339 & .000 \\
\hline & & $0.4-0.2$ & 14.222 & 8.019 & 11.897 & .000 \\
\hline & & $0.6-0.2$ & 27.111 & 12.102 & 15.028 & .000 \\
\hline & \multirow[t]{3}{*}{ Left arm } & $0.6-0.4$ & 14.600 & 12.294 & 7.966 & .000 \\
\hline & & $0.4-0.2$ & 12.022 & 8.228 & 9.801 & .000 \\
\hline & & $0.6-0.2$ & 26.622 & 15.246 & 11.713 & .000 \\
\hline \multirow[t]{9}{*}{ Round side down } & \multirow[t]{3}{*}{ Both arms } & $0.6-0.4$ & 11.777 & 13.689 & 5.771 & .000 \\
\hline & & $0.4-0.2$ & 6.888 & 8.942 & 5.168 & .000 \\
\hline & & $0.6-0.2$ & 18.666 & 16.497 & 7.590 & .000 \\
\hline & \multirow[t]{3}{*}{ Right arm } & $0.6-0.4$ & 11.088 & 7.603 & 9.783 & .000 \\
\hline & & $0.4-0.2$ & 10.155 & 7.403 & 9.201 & .000 \\
\hline & & $0.6-0.2$ & 21.244 & 10.260 & 13.889 & .000 \\
\hline & \multirow[t]{3}{*}{ Left arm } & $0.6-0.4$ & 18.311 & 16.629 & 7.387 & .000 \\
\hline & & $0.4-0.2$ & 12.088 & 9.600 & 8.447 & .000 \\
\hline & & $0.6-0.2$ & 30.400 & 23.077 & 8.837 & .000 \\
\hline
\end{tabular}

Table 3

STATISTICAL DESCRIPTION OF PAIRED DIFFERENCES OF THE RESULTS OF THE STATICAL BALANCE STANDARD EVALUATION IN FACIAL PLANK POSITION BETWEEN THREE BOSS BALL PRESSURE LEVELS INFLATION 
According to the findings in our study, we have identified other research that, depending on the position of the body on Bosu Ball, demonstrates that unstable surface exercises using dynamic pillows for the lower extremities may result in higher activities than exercises in the same position planning at the upper limbs on an unstable or stable surface [16]. Performing exercises on an unstable surface requires a higher level of proprioceptive muscle contraction suited to the intensity of the visual stimulus, compared to the same execution on a stable surface [1,35-36]. Making movements on unstable surfaces causes the reduction of absolute force especially in the case of use of segmental or general resistance exercises [37-39]. The results highlighted by our study will contribute to the completion of knowledge aimed at optimizing human motor and health potential developed by recent studies [40-45].

\section{Conclusions}

The lower the pressure of the ball is, the stable handbalance stability is, which is of major relevance to the design of exercise and kineto- and physiotherapy programs. According to our study, the difficulty in motric execution is directly related to the pressure drop of the Bosu ball. Testing of stable hand-balance on round side up has recorded superior results compared with the round-side down of Bosu ball. The use of both Bosu ball surfaces and the relationship with specific technical and elastic characteristics at different inflation pressures determine the optimization of physical fitness, proprioception and postural control in motor, kinetoprophylactic and kinetotherapeutic programs. We recommend manufacturers to write the following pressure levels in accordance with the level of practicing: $0.6 \mathrm{~atm}$. for small difficulty exercises, $0.4 \mathrm{~atm}$. for medium difficulty exercises and $0.2 \mathrm{~atm}$. for high difficulty exercises.

\section{References}

1.BADAU, D.; BADAU, A.; CLIPA, A., Mat. Plast. 55, no. 4, 2018, p. 600602 ;

2.TATU, R.F., IVASCHESCU, V., BOJ IN, F., HURMUZ, M., TATU, C., Mat.Plast. 51, no. 1, 2014, p. 28-31;

3.PAHONIE, R.C., STEFAN, A., ADOCHIEI, I.R., COSTULEANU, C.L., ANDRUSEAC, G.G., UNGUREANU, G., SARDARU, D.P., Mat.Plast. 54, no.2, 2017, p. 396-401;

4.POPESCU, A., MANDRU L. Bulletin of the Transilvania University of Braov Series V: Economic Sciences, 9 (58), no. 2, 2016, p. 203-212;

5.WING, C.H., ACSMS HEALTH FIT J., 18, no. 4, 2014, p. 5-7;

6.ELFATEH, A., Science, Movement and Health, 16, no. 2 Suppl., 2016 p. 273-279;

7.DUSA, F.S., BADAU, A., BADAU, D., TRAMBITAS, C., BRINZANIUC, K., Mat.Plast., 54, no. 4, 2017, p. 606-609;

8.*** https://patents.google.com/patent/US9700756B2/en; Accesed in January 2019.

9.ROMERO-FRANCO, N., MARTINEZ-LOPEZ, E.J., LOMAS-VEGA, R., HITA-CONTRERAS, F., OSUNA-PEREZ, M.C., MARTINEZ-AMAT, A., J Strength Cond Res., 27, no. 8, 2013, p. 2189-2197;

10.LUBETZKY, A.V., KARY, E.E., HAREL, D., HUJ SAK, B., PERLIN, K., PHYSIOTHER THEOR PR., 34, no. 12, 2018, p. 935-950;

11.LAUDNER, K.G.; KOSCHNITZKY, MATTHEW M. J Strength Cond Res., 24, no. 1, 2010, p. 218-222 LUBERTZKY, V.A., MCCOY, S.W., PRICE, R., CIOL, M.A., J Strength Cond Res., 29, no. 10, 2015, p. 29072918;

12. LUBERTZKY, V.A., MCCOY, S.W., PRICE, R., CIOL, M.A., J Strength Cond Res., 29, no. 10, 2015, p. 2907-2918.

13.MEREUTA, C.; MEREUTA, E. Procedia Social and Behavioral Sciences, 84, 2013, p. 1606-1610;

14.ZEMKOVA, E., JELEN, M., RADMAN, I., SVILAR, L., HAMAR, D., MED SPORT, 70, no. 1, 2017, p. 36-49;

15.SAETERBAKKEN, A.H., ANDERSEN, V., JANSSON, J., KVELLESTAD, A.C., FIMLAND, M.S., J Strength Cond Res., 28, no. 12, 2014, p. 35153522:
16.BADAU A. Physical education of students, 21, no. 4, 2017, p. 158$164 ;$

17. DO, Y.C., YOO, W.G.,J Phys Ther Sci, 27, 2015, p. 169-70;

18.TONG, T.K., WU, S., NIE, J., Phys Ther Sport, 15, 2014; p. 58-63;

19.HALMACIU, I., SUCIU, B.A., TRAMBITAS, C., VUNVULEA, V., IVANESCU, A., CLIPA, A., ADASCALITEI, P., BRINZANIUC, K., FODOR, D., Mat.Plast., 55, no. 3, 2018, p. 414-418;

20.SUCIU, B.A., HALMACIU, I., FODOR, D., TRAMBITAS, C., GODJ A D., CLIPA A., NICOLESCU C., BRINZANIUC K., VUNVULEA V., Mat. Plast., 55, no.3, 2018, p.380-384;

21.SUCIU B.A., HALMACIU I., VUNVULEA V., BRINZANIUC K., Eur. J. Cardiothorac. Surg., 53,2018,nr.4,p.895-896;

22.MUHLFAY, G., FABIAN., Z., NEAGOE, R., HORVATH, K.U. Mat.Plast. 55, no.3, 2018, p. 431-433;

23.POP T. S., POP A. M., OLAH P., TRAMBITAS C., Medicine, 97, 2018, p. 1- 4;

24.POP, T. S.,. POP, A.M., TRAMBITAS MIRON, A.D., BRINZANIUC, K., GURZU, S, TRAMBITAS, C, Mat.Plast. 55, no. 4, 2018, p. 691-695;

25.TRAMBITAS, C., POP, T.S., TRAMBITAS MIRON, A.D., DOROBANTU, D.C., BRINZANIUC, K. Rev.Chim.(Bucharest), 68, no. 2, 2017, p. 387389;

26.BADR, N. Science, Movement and Health, 3, no. 2, 2013, 498-505 27.KÜMMEL, J., KRAMER, A., GIBOIN, L.S., GRUBER, M. Sports Med., 46, 2016, p. 1261;

28.J IN, L., KWANGHYUN, J., HYUNA, L., JAEYEON, S., JAELIM, C., SEUNGBEOM, K., BYOUNG-HEE, L. Phys Ther Rehabil Sci. 5, 2016, p. 29-33;

29.CALATAYUD, J., CASANA, J., MARTIN, F., JAKOBSEN, M.D., COLADO, J.C., GARGALLO, P., JUESAS, A., MUNOZ, V., ANDERSEN, L.L. Musculoskelet Sci Pract. 28, 2017, p. 54-58;

30.CORTELL-TORMO, J.M., GARCIA-J AEN, M., CHULVI-MEDRANO, I., HERNANDEZ-SANCHEZ, S., LUCAS-CUEVAS, Á.G., TORTOSAMARTINEZ. J. J Strength Cond Res. 32, no. 8, 2017 p. 2255-2262;

31.CALATAYUD, J., CASAÑA, J., MARTIN, F., JAKOBSEN, M.D., COLADO, J.C., ANDERSEN, L.L. Am J Phys Med Rehabil. 96, no. 10, 2017, p. 694-699;

32.ROMERO-FRANCO, N., MARTINEZ-AMAT, A., MARTINEZ-LOPEZ, E.J. REV INT MED CIENC AC. 13, no. 51, 2013, p. 437-451;

33.ABD, E., MAHMOUD, A., ELHADY, A., HEBATALLAH, S. INTERNATIONAL J OURNAL OF THERAPY AND REHABILITATION, 25, no. 9,2018 , p. 467-474;

34.MENAYO, R., ENCARNACION-MARTINEZ, A., MA GEA-GARCIA, G., MARCOS-PALDO, P.J. Int. J. Sport Psycol. 45, no. 5, 2014, p. 452-468; 35.COSIO-LIMA, LM., REYNOLDS, KL., WINTER, C., PAOLONE, V., JONES, MT. J Strength Cond Res. 17, 2003, p. 721-725;

36.NORWOOD, J.T., ANDERSON, G.S., GAETZ, M.B., TWIST, P.W. J Strength Cond Res. 21, 2007, p. 343-347;

37.MCBRIDE, J.M., LARKIN, T.R., DAYNE, A.M., HAINES, T.L., KIRBY, T.J . Int J Sports Physiol Perform. 5, no. 16, 2010, p. 177-183;

38.SAETERBAKKEN, A.H., FIMLAND, M.S. J Strength Cond Res. 27, no. 17, 2013, p. 1101-1107;

39.SAETERBAKKEN, AH AND FIMLAND, MS. J Strength Cond Res. 27, 2013, p. 130-136;

40.FILHO, B., MIRON, ALINA DIA, SATOH, I., GENSEL, J., MARTIN, H.: Modeling and Measuring Quality of Context Information in Pervasive Environments. AINA2010: 690-697

41.DRAGOI, R.G, AMARICAI, E.C, DRAGOI, M., POPOVICIU H, AVRAM, C. Ann. Rheum. Dis. 74, no 2, 2015, p. 135-136;

42.AVRAM C., DRAGOI, R.G., POPOVICIU, H., DRAGOI, M.; AVRAM, A.; AMARICAI, E. Clin. Rheumato. 35, no 8, 2016, p. 2017-2022;

43.MEREUTA, C., MEREUTA, E. FOURTH INTERNATIONAL CONFERENCE ON EDUCATION AND SPORTS EDUCATION (ESE 2013), PT II, Book Series: Lecture Notes in Management Science, 12, 2013, p. 595-598;

44.COJ OCARU, A.M; COJOCARU, M. European Proceedings of Social and Behavioural Sciences, 30, 2017, p. 370-376;

45.ION-ENE, M., ROSU, D., NEOFIT, A. Procedia-Social and Behavioral Sciences, 137, 2014, p. 37-42.

Manuscript received: 7.12 .2018 